\title{
Correction to: Explaining the density of post-communist interest group populations-resources, constituencies, and regime change
}

\author{
Rafael Labanino $^{1}$ (D) $\cdot$ Michael Dobbins $^{1} \cdot$ Brigitte Horváthová $^{1}$
}

Published online: 30 August 2021

(c) The Author(s) 2021

\section{Correction to: Interest Groups \& Advocacy https://doi.org/10.1057/s41309-021-00130-3}

Unfortunately, the captions for Figure 1 and Table 3 are incorrect in the original version of this article.

The caption for Fig. 1 reads:

"Mean number of post-transition organisations per 1989/2018 density ratio quartiles in energy, higher education and healthcare group populations in 2018 - Czechia, Hungary, Poland, and Slovakia”

And it should be:

"Mean number of post-transition organisations per 1989/2018 density ratio quartiles in energy, higher education and healthcare group populations in 2018 - Czechia, Hungary, Poland, and Slovenia"

The original article can be found online at https://doi.org/10.1057/s41309-021-00130-3.

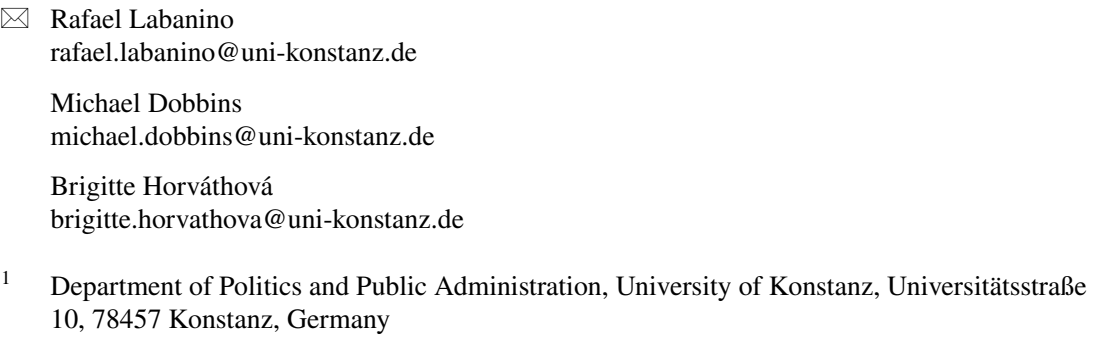


The caption for Table 3 reads:

"The density of Hungarian, Polish and Slovenian health care, higher education and energy policy interest groups"

\section{And it should be:}

"The density of Czech, Hungarian, Polish and Slovenian health care, higher education and energy policy interest groups"

Open Access This article is licensed under a Creative Commons Attribution 4.0 International License, which permits use, sharing, adaptation, distribution and reproduction in any medium or format, as long as you give appropriate credit to the original author(s) and the source, provide a link to the Creative Commons licence, and indicate if changes were made. The images or other third party material in this article are included in the article's Creative Commons licence, unless indicated otherwise in a credit line to the material. If material is not included in the article's Creative Commons licence and your intended use is not permitted by statutory regulation or exceeds the permitted use, you will need to obtain permission directly from the copyright holder. To view a copy of this licence, visit http://creativecommons.org/licen ses/by/4.0/.

Publisher's Note Springer Nature remains neutral with regard to jurisdictional claims in published maps and institutional affiliations. 